\title{
A CASE OF BELladonNA POISONING.
}

Mr. Editor, - A case of accidental poisoning by belladonna occurred here lately. It seems to me valuable for publication, because a large quantity of the drug was absorbed without fatal result (and it is the opinion of the attending physicians that the result was not decided by the treatment), and because the details can be given with accuracy.

The patient, who is also the writer, is a man twenty-eight years of age, of good physical development, and free from organic disease. When twelve years of age, at a boarding-school in Brattleboro, Vermont, he was dangerously ill with cerebro-spinal meningitis, followed by a slow convalescence. His father, Dr. Luther Parks, reported the case at the time in the Journal. In the fall of 1871 he began his medical studies in Philadelphia, and remained there as student and practitioner five years. In that time his health was often depressed by overwork, and he had four distinct illnesses, - an attack of measles, two carbuncles, and an attack of nervous prostration after mental strain. Although the last two summers have been passed in the singularly restful climate of Mattapoisett, his nervous system was in an impaired state at the time of his late accident.

Friday afternoon, January $25 \mathrm{th}$, he was suffering from pain in the joints of his lower extremities and vesical irritability, due to exposure to a cold rainstorm. For the relief of the latter trouble he called soon after dinner at a drug store for some fluid extract of buchu, and a bottle of fluid was given him by the proprietor labeled "Fluid Extract of Buchu." A few minutes after two o'clock he measured carefully one drachm of the drug, and, having filled the medicine glass to the brim with water, swallowed the whole contents without tasting it. A few minutes past four he measured a drachm and a quarter of the fluid, added water, and drank as before. In the interval between the two draughts he was occupied in reading, writing, and in other ways, and, though he felt strangely, the sensation did not demand particular attention. Immediately after the second draught he walked out, and noticed at once dimness of vision, dryness of mouth and throat, constriction of fauces, a feeling as if the tongue were enormously swollen, dullness of intellect, and weakness of knees, with want of muscular coördination. Having walked a half mile by himself, he joined a young lady and escorted her to her residence, and thence went to his room, - in all a distance of fully a mile and a half. Upon parting from the lady he stopped in the street and conversed with a medical friend. That gentleman has since told him that he noticed that something was wrong about him. Having reached his room and built a fire, at six o'clock he became alarmed at his symptoms, called his landlord to his assistance, and told him he thought he had been poisoned. The landlord acted with prompt decision and good judgment. 'The patient was running up and down the room, drinking large draughts of water, upsetting pitchers, and in danger of falling. His landlord in a tone of authority ordered him to bed, and was promptly obeyed, and he was held there throughout the night, in spite of his extreme restlessness. Medical aid was summoned at once. It was noted at this time that the tongue was very red and the secretion of urine increased. 
There were hallucinations like those of delirium tremens, disagreeable, vanishing instantly, and immediately after their departure the patient was aware of their unreality. The yellow corpse of a tall man, shrouded in white, tried to share the patient's bed with him, and the unwelcome visitor was promptly ejected. A crimson serpent came from the foot of the bed, with the design of fastening upon the patient's neck. Rising to his knees, he with his fist drove the serpent's head deep into the bed, and instantly the apparition vanished. He asked his attendant (for he was practically blind) if the blanket had a red border to account for the hallucination. There were large sea-turtles about the room, such as he had seen in the Pacific. After an hour or two of sleep in the early morning the delusions became agreeable, and continued all day. While riding out in the afternoon with a medical friend, trees became personified to him as people in fantastic costumes. There was no diplopia at any time. In the morning there was severe pain in both renal regions, which he partially relieved by pressure with his fists, the elbows planted in the bed, and the body raised in that way quite off the mattress. There was some strangury the next evening.

Thus far this report is given from the patient's memory and note-book. With regard to the time when assistance was first summoned, further details are given derived from medical and other attendants. The delirium was " most busy." Picking things from the bedclothes, rising in bed to gather things from the pictures and walls, muttering to himself, he had little time to notice those about him. He answered short questions correctly. When the first physician arrived, shortly before eight o'clock, he found him with flushed face, pulse as full and strong as usual, and very rapid, but the wrist could not be held long enough to count it. Delirium tremens was considered; also his having been drugged. There was no one about who knew the patient's habits, nor where he had been during the day. The physician was sure that the effect of the narcotic had reached its height, and that there was no danger to life. Bromide of potassium and morphia were ordered, but the patient, though aware that he was ill, resisted treatment, and but little of the bromide was swallowed. One half grain of the morphia in whisky was forcibly administered. Shortly before nine o'clock a second physician called. He was sure that the mischief had been caused by atropia, in spite of the patient's declaration to the contrary. The lighted candle held before the widely dilated pupils caused pain. The proper treatment having been pursued, he left no directions. The next morning he tested the patient's vision by passing his forefinger close before his eyes. It was not seen.

In the morning the druggist called, and confessed that he had given belladonna for buchu.

There was no vomiting. Urine escaped during sleep, but otherwise there was neither incontinence nor retention.

A specimen of the urine passed between Saturday and Sunday mornings was tested by the writer. After prolonged boiling and addition of nitric acid fully ten per cent. of albumen was deposited after standing twelve hours. Fifty cc. of urine deposited 1 cc. of sediment (two per cent.). Under the microscope this was found to be squamous epithelium, with a few crystals (modified 
form) of triple phosphate. The urine, and also the pupils, became normal in less than a week. The face remained flushed for days.

Great mental and physical prostration, sleeplessness, and pain in the left kidney followed the accident, and are still present at this date. The pain was relieved by a Turkish bath in San Francisco not long ago, but has returned to a slight degree.

The fluid extract came from Tilden \& Co., New Lebanon and New York city, $\mathbf{N}$. Y. It is being tested by competent chemists, and any valuable results will be sent to the JournaL.

This report is published by the kind permission of the attending physicians, to whom it has been submitted for approval. Your obedient servant,

Edward L. Parks.

Santa Barbara, Cal., February 20, 1878.

COMPARATIVE MORTALITY-RATES.

\begin{tabular}{|c|c|c|c|c|c|}
\hline & \multirow{2}{*}{$\begin{array}{c}\text { Kstimated Pop- } \\
\text { ulation, July } 1 \text {, } \\
1878 .\end{array}$} & \multirow{2}{*}{$\begin{array}{l}\text { Deaths during } \\
\text { week ending } \\
\text { April 18, 1878. }\end{array}$} & \multicolumn{3}{|c|}{ Annual Death-Rates per 1000 living. } \\
\hline & & & $\begin{array}{l}\text { For the } \\
\text { Week. }\end{array}$ & $\begin{array}{c}\text { For the Year } \\
\text { 1877. }\end{array}$ & $\begin{array}{l}\text { Mean of ton } \\
\text { Years, } 68-77 .\end{array}$ \\
\hline New York. & $1,093,171$ & 509 & 24.21 & 24.32 & 28.71 \\
\hline Philadelphia. & 876,118 & 304 & 18.04 & 18.80 & 21.54 \\
\hline Brooklyn. & 549,438 & 190 & 17.98 & 21.51 & 25.50 \\
\hline Chicago. & 460,000 & 106 & 11.98 & 17.83 & 22.39 \\
\hline Boston. & 375,476 & 121 & 16.76 & 20.10 & 24.34 \\
\hline Providence. & 100,000 & 36 & 18.72 & 18.81 & 19.20 \\
\hline Lowell. & 55,798 & 18 & 16.77 & 19.09 & 22.50 \\
\hline Worcester. & 54,937 & 18 & 17.05 & 14.07 & 22.30 \\
\hline Cambridge. & 53,547 & 15 & 14.56 & 18.69 & 20.83 \\
\hline Fall River. & 53,207 & 29 & 28.35 & 21.35 & 24.96 \\
\hline Lynn. & 35,528 & 19 & 27.82 & 20.42 & 19.67 \\
\hline Springfield. & 33,981 & 3 & 4.59 & 16.04 & 19.77 \\
\hline Salem. & 27,140 & 8 & 15.33 & 20.28 & 21.15 \\
\hline
\end{tabular}

TAPE-WORM.

Mr. Editor, - A notice is at the present time being pretty extensively circulated among physicians, in which a number of names are given as references, by a person who takes this means of advertising a small and quackish pamphlet on tape-worm. The names are used (so far as I have been able to ascertain) without a shadow of authority. The pamphlet contains nothing worth reading, except, perhaps, the formula which its author uses to effoct the removal of the parasite. Here it is : A purge at night. Three or five grains of calomel in the morning. Immediately afterwards four or eight ounces of an infusiou of pomegran ate root (prepared by pouring a quart of cold water over half a pound of the root and boiling down to a pint) is given, and repeated in two or three hours if not effective. Should the worm be only partially expelled, an enema of salt and water is used. Nausea is prevented by sucking a lemon. Fasting is prescribed from the beginning of the treatment until after the expulsion of the parasite.

F. G. M. 